\title{
THE EARLY RECOGNITION OF STREPTOCOCCI AS CAUSES OF DISEASE
}

\author{
by \\ LEONARD G. WILSON*
}

On 9 April 1880, a young Scottish surgeon and bacteriologist, Alexander Ogston, reported to the German Surgical Congress in Berlin his observations of micrococci, growing sometimes in clusters and sometimes in chains, in the pus of acute abscesses. ${ }^{1}$ Ogston was no stranger to Germany. The son of Francis Ogston, professor of medical jurisprudence in the University of Aberdeen, Alexander Ogston began his medical studies at Aberdeen, but during the summer of 1863 he travelled to Prague, where he spent several weeks attending lectures and clinics informally. In October 1863, he went to Vienna, where he registered as an "extraordinary student" to attend the lectures of Joseph Hyrtl, Ernst Brücke, Carl Rokitansky, Johann Oppolzer, Johann Dumreicher, and others, but except for Hyrtl's lectures in anatomy, Ogston soon ceased to go to the public university lectures in favour of small private classes on new medical specialities, such as ophthalmology. The following summer of 1864, he attended clinics in Berlin, where he studied under Rudolf Virchow, Albrecht Graefe, and Bernhard Langenbeck. In the autumn of 1864 , Ogston returned to Aberdeen, where he completed his medical studies, receiving the MB, CM degrees in 1865 and the MD degree in $1866 .{ }^{2}$ In 1870 , he became a junior surgeon at the Aberdeen Royal Infirmary; he acted initially as ophthalmic surgeon and anaesthetist. Shortly before his appointment, Ogston had learned that in Glasgow Joseph Lister had discovered a means of preventing the formation of pus and blood poisoning in operation wounds, a discovery astonishing to him because at the Aberdeen Royal Infirmary all operation wounds suppurated. In 1870 , Ogston went to Edinburgh to call on Lister, who had just moved from Glasgow to the professorship of clinical surgery in the University of Edinburgh. Lister explained to him the principles upon which the antiseptic method was based, and suggested that he go to Glasgow to see how antiseptic surgery was being practised at the Glasgow Royal Infirmary. There, Lister's former assistant and successor, Hector Cameron, took Ogston to the wards of the infirmary to see surgical patients who had been operated on

\footnotetext{
*Leonard G. Wilson, PhD, Professor and Head, Department of History of Medicine, University of Minnesota, 506 Mayo, 420 Delaware Street S.E., Minneapolis, Minnesota 55455, USA.

'Alexander Ogston, 'Ueber Abscesse', Arch. klin. Chir., 1880, 225: 588-600. An English translation of this article has recently been published: Alexander Ogston, 'On abscesses', trans. W. Witte, in Alexander Macdonald and George Smith (editors), The staphylococci: proceedings of the Alexander Ogston centennial conference, Aberdeen, 1981, pp. 277-285.

${ }^{2}$ Alexander Ogston, 'Autobiographical writings', in Walter H. Ogston et al. (editors), Alexander Ogston, K.C.V.O. Memories and tributes of relatives, colleagues and students, with some autobiographical writings, Aberdeen, 1943, pp. 53-110, especially pp. 63-83. Cf. George Smith, 'Ogston the bacteriologist', in Macdonald and Smith (editors), op. cit., note 1 above, pp. 9-21.
} 
antiseptically. Ogston recalled: "I was shown a knee-joint which had been opened, and after instruction, was allowed to handle and examine it. There could be no room for doubt. The wound made into the joint was there, but where was the inflammation that ought fatally to have followed? There was none. The limb was perfectly well, the wound clean and healing, and not a trace visible of what I would have deemed to be the inevitable." 3 Deeply impressed, Ogston returned to Aberdeen to begin the complex task of introducing antiseptic surgical methods at the Aberdeen Royal Infirmary.

During the 1870s, Lister's new method of antiseptic surgery was adopted more rapidly in Germany than in Great Britain, and Ogston attended the meetings of the German Surgical Congress principally to keep abreast of new developments in antiseptic surgery. In 1874, he was appointed a full surgeon at the Aberdeen Royal Infirmary, and in April 1877, he delivered before the German Society for Surgery a paper on the operative treatment of genu valgum (knock-knee), a condition then common in Scotland because of the prevalence of rickets, but upon which surgical operation could be justified only if it could be done safely. ${ }^{4}$ Thus Ogston's surgical work was connected inseparably to the development of antiseptic surgery.

In 1876, Robert Koch published his study of the anthrax bacillus, followed in 1878 by his monograph on the aetiology of wound infections. ${ }^{5}$ Koch produced septicaemia in a series of mice by inoculating the first mouse with a drop of putrid blood, the second mouse with one-tenth of a drop of blood from the heart of the first mouse, the third with blood from the heart of the second, and so on through seventeen mice, each of which died of the same general septicaemia. In the blood of the mice Koch detected multitudes of bacilli, less than one micron in length, and traced the path by which the bacilli penetrated into the body from the inoculation site. Thus he demonstrated that the general infectious disease from which the mice died was caused by the growth and spread of a particular micro-organism in their tissues. Koch inoculated a rabbit with a putrid fluid derived from a small piece of mouse skin macerated in water. The rabbit became ill and died on the fifth day. He then injected ten drops of its heart's blood into a second rabbit, which died within forty hours, with pathological changes similar to those of the first rabbit. A third rabbit injected with three drops of blood died in fifty-four hours in a like manner, of what was clearly a general infective disease. When he examined the tissues of the diseased rabbits microscopically, Koch found large numbers of micrococci, usually single or in pairs.

In order to detect bacteria in the tissues of mice and rabbits, Koch used aniline dye stains such as methyl violet, fuchsin, or aniline brown, following the methods developed at Breslau by Carl Weigert. An equally essential element in Koch's successful detection of bacteria in animal tissues was the use on his microscope of an Abbe condenser, made by Carl Zeiss of Jena, that permitted the elimination of the effects of diffraction so as to reveal the brightly stained bacteria.

In 1868, chain-forming micrococci had been seen by the German surgeon Theodor

\footnotetext{
${ }^{3}$ Ogston, op. cit., note 2 above, p. 95.

${ }^{4}$ Alexander Ogston, 'Zur operativen Behandlung von Genu valgum', Arch. klin. Chir., 1877, 21: 537-546.

${ }^{5}$ Robert Koch, 'Die Aetiologie der Milzbrand-Krankheit, begrundet auf die Entwicklungsgeschichte der Bacillus anthracis', Beitr. Biol. Pfl., 1876, 2: 277-310; Robert Koch, Untersuchungen über die Aetiologie der Wundinfektionskrankheiten, Leipzig, 1878.
} 
Billroth, who named them Streptococcus (from the Greek streptos $=$ a chain and $k o k k o s=$ a berry or seed). ${ }^{6}$ Billroth had seen the streptococci in the pus of wounds, and he thought them a phase of his coccobacteria septica, that is, coccus bacteria that grew secondarily in the septic secretions of wounds. ${ }^{7}$

With the repeated demonstrations of the success of antiseptic surgery, the question remained regarding the cause of the acute inflammation and suppuration that occurred when the methods of antiseptic surgery were not used, or when they failed. In May 1874, the German surgeon H. R. Ranke, working in Richard Volkmann's clinic at Halle, undertook to determine whether micro-organisms occurred under Listerian surgical dressings. Ranke examined under the microscope the discharges from the wounds of fifteen patients treated according to Lister's method and found in all of them coccobacteria, sometimes in pairs, occasionally in chains, and more rarely accompanied by rod-shaped forms. The number and combinations of microorganisms were so variable that Ranke concluded that no clear relationship existed between the occurrence of the micro-organisms and the wound-healing process. The richest growth of streptococci occurred in an amputation patient who remained quite free of fever. Therefore, Ranke thought, the cause of wound diseases could not be attributed simply to coccobacteria. ${ }^{8}$

Ranke's observations were promptly criticized by Edwin Klebs of Prague, who suggested that Ranke had not followed a truly Listerian antiseptic method, but something more like open wound treatment. ${ }^{9}$ In 1876, Ranke replied to Klebs with detailed descriptions of cases to show that he had followed Lister's mode of antiseptic treatment faithfully, but that, even where the operation wound healed without inflammation, the discharges contained micro-organisms. ${ }^{10}$ Because Ranke was an assistant in Volkmann's clinic, where Lister's methods were being used regularly with excellent results, his claim to have followed Listerian procedures could not easily be denied.

In 1876, when, after a year of medical study at Vienna and Strasburg, William Watson Cheyne returned to Edinburgh to become house surgeon to Joseph Lister, he took up the question of the occurrence of micro-organisms in the discharges of wounds. In January 1877, Watson Cheyne began to inoculate samples of discharges from wounds into flasks containing sterilized cucumber infusion, a medium which, after various trials, he had found best suited to the growth of micro-organisms. He found either that the cucumber infusion remained clear, without developing any micro-organisms, and showing thereby that no micro-organisms were present in the wound, or that the fluid became turbid from the growth of micrococci. In both cases, the wound healed without inflammation, and there was nothing in its appearance to

\footnotetext{
${ }^{6}$ Theodor Billroth, Untersuchungen über die Vegetationsformen von Coccobacteria septica und den Antheil, welchen sie an der Entstehung und Verbreitung der accidentellen Wundkrankheiten haben. Versuch einer wissenschaftlichen Kritik der verschiedenen Methoden antiseptischer Wundbehandlung, Berlin, 1874, pp. 10-11.

${ }^{7}$ Ibid., p. viii.

${ }^{8}$ H.R. Ranke,'Die Bacterien-Vegetation unterdem Lister'schen Verbande',Zentbl. Chir., 1874, 1:193-194.

9 E. Klebs, 'Beiträge zur Kenntnis der pathogenen Schistomyceten', Arch. exp. Path. Pharmak., 1875, 3: 305-324, p. 315.

${ }^{10}$ H. R. Ranke, 'Zur Bakterienvegetation unter dem Lister'schen Verbande', Dt. Z. Chir., 1876, 7: 63-68.
} 


\section{Leonard G. Wilson}

tell whether micro-organișms were present or not. ${ }^{11}$ Watson Cheyne thus confirmed Ranke's observation that micrococci could be present in a wound treated antiseptically without interfering with the course of healing. By contrast, in wounds not treated antiseptically, Watson Cheyne found micro-organisms always present, and in almost all such wounds he found what he called bacteria, by which he meant rod-shaped micro-organisms. Their presence might be indicated by a foul smell. If bacteria gained entrance to a wound, they might grow within the wound beneath an antiseptic dressing. Although Theodor Billroth and Ernst Hallier had denied that micrococci were distinct from bacteria, in Watson Cheyne's experience they were distinct and he noted that in 1872 Georg Rindfleisch, and in 1875 Ferdinand Cohn, had also considered them distinct. ${ }^{12}$

Watson Cheyne found that when he grew micrococci in milk, meat infusion, or cucumber infusion, they produced only slight changes in the medium. The growth of the micrococci produced a small increase in acidity, a very faint sour odour, and a slight change in taste. Thus, when micrococci grew in wounds or beneath the surface of antiseptic dressings, they generated no smell in the discharges nor any inflammation in the tissues. By contrast, bacteria always altered the medium in which they grew, making it acrid, disagreeable in taste, and sometimes foul-smelling.

Although Watson Cheyne noted that various authors had detected micrococci along the margin of the reddened skin in erysipelas, in the peritoneal fluid in puerperal peritonitis, in septic disease, and in ulcers on the heart valves in endocarditis, he did not think the evidence was sufficient to show that micrococci were the causes of the diseases. To test his view, Watson Cheyne injected cucumber infusion containing micrococci into the jugular vein of one rabbit, and a similar infusion containing bacteria into another rabbit. The rabbit inoculated with micrococci remained healthy, whereas the rabbit inoculated with bacteria became ill and died. Watson Cheyne wrote that whether micrococci were obtained from wounds, from the air, from tap-water, from unopened abscesses, or from rabbits, they were equally harmless. Nevertheless, Watson Cheyne recognized that there existed many forms of micrococci, and that Robert Koch had shown that pyaemia in the rabbit was caused by the growth of micrococci in the blood, but he thought that the harmful forms of micrococci must be relatively rare. ${ }^{13}$

In distinguishing the pathogenic capabilities of the micrococci from those of the bacteria (i.e., rod-shaped micro-organisms), Watson Cheyne followed the lead of John Burdon Sanderson, who, in a series of lectures on 'The infective processes of diseases' delivered at the University of London during the winter 1877-78, had drawn the same distinction. ${ }^{14}$ But Watson Cheyne drew back from Burdon Sanderson's further

${ }^{11} \mathrm{~W}$. Watson Cheyne, 'On the relations of organisms to antiseptic dressings', Trans. path. Soc. Lond., 1879, 30: 557-582.

12 Ibid.,p. 565. Cf. Ferdinand Cohn, 'Untersuchungen über Bacteria, III', Beitr. Biol. Pfl., 1875, 3: 141-207; Georg Rindfleisch, 'Untersuchungen über niedere Organismen', Virchows Arch. path. Anat. Physiol., 1872, 54: 108-120, 396-407. In 1872, Georg Rindfleisch (1836-1908) wàs professor of pathological anatomy at Bonn.

${ }^{13}$ Cheyne, op. cit., note 11 above, p. 568.

14 J. Burdon Sanderson, 'Lectures on the infective processes of disease,' Br. med. J., 1877, ii: 879-881, 913-915; 1878, i: 1-2, 45-47, 119-120, 179-183. 
opinion that bacteria were present in the bodies of healthy animals during life. ${ }^{15}$ Instead, he demonstrated experimentally that when portions of such organs as liver, spleen, kidney, pancreas, muscle, or heart were removed aseptically from the body of a healthy rabbit immediately after it was killed, and placed in sterile cucumber infusion, neither the organs nor the infusion underwent any change, showing that microorganisms were not present in the blood or tissues of the organs of a healthy animal. ${ }^{16}$ In a diseased animal, the case might be different.

To investigate the occurrence of micro-organisms in human disease, Watson Cheyne examined abscesses when opened. In chronic abscesses, he found no organisms by microscopic examination alone. Although Watson Cheyne probably used a very good microscope of the time, he probably did not use one equipped with an Abbe condenser and oil immersion objective lens, which in 1878 represented the latest refinement in microscopic apparatus. From thirty-two acute abscesses, he drew pus which he inoculated into infusions. Only seven, less than a quarter of the total, showed micrococci, while the remainder yielded no organisms. Watson Cheyne did note that "the abscesses which I have examined were not as a rule very acute." ${ }^{17}$ He observed also that micrococci were much less sensitive to carbolic acid than bacteria, so that at low concentrations of carbolic acid, in which bacteria would not grow, micrococci monopolized the culture. Moreover, as micrococci grew in infusions containing carbolic acid, they became tolerant of it, so that they could grow and flourish at higher concentrations of carbolic acid than at the beginning. Thus as micrococci grew in the discharges of wounds covered with carbolic acid dressings, their ability to grow improved.

At the Aberdeen Royal Infirmary some time in 1878 or 1879 , Alexander Ogston attended a young man, James Davidson, who was suffering from an extensive suppurating phlegmon of the leg. From the phlegmon, Ogston drew some pus through the unbroken skin into a clean phial, and took it home to examine under the microscope. "My delight may be conceived", he wrote later, "when there were revealed to me beautiful tangles, tufts and chains of round organisms in great numbers, which stood out clear and distinct among the pus cells and debris, all stained with aniline violet solution ...."18 From his initial observation, Ogston went on to examine pus from every abscess that he encountered in his own practice and in that of his medical friends. Through a grant from the British Medical Association, he obtained from Jena a large Zeiss microscope equipped with an Abbe condenser and an oil immersion lens, the kind of microscope that Robert Koch had recommended for the observation of bacteria. By April 1880, when Ogston made his first report of his findings to the German Medical Congress, he had studied pus from sixty-four abscesses. In seventeen the pus contained only micrococci in chains, while in thirty-one the micrococci occurred in clusters like bunches of grapes. In fourteen abscesses micrococci occurred in both chains and clusters, and in two abscesses they occurred in pairs. ${ }^{19}$ Occasionally,

15 Ibid., 1878, i: 119.

16 Cheyne, op. cit., note 11 above, p. 571 .

17 Ibid., p. 574.

18 Ogston, op. cit., note 2 above, p. 98.

19 Ogston, op. cit., note 1 above, p. 591. 
bacillus or spirillum forms of bacteria occurred together with the micrococci, but such abscesses gave off a foul odour and were usually near the anus or associated with decayed teeth.

To determine whether the micrococci actually were the cause of inflammation, Ogston injected material from the abscesses into guinea pigs and mice. Pus from cold abscesses, containing no micrococci, exerted no effect whereas pus from acute abscesses, swarming with micrococci, made the animals severely ill, and if Ogston killed them during the first week, he found an abundance of micrococci in the pus of the abscess that had formed at the injection site and in the surrounding tissues. ${ }^{20}$ Like Watson Cheyne, Ogston observed the micrococci growing in wound secretions without any apparent harmful effect, and was puzzled why the organisms were harmless on the surface of wounds when in deep abscesses they were so active in producing inflammation. When he cultivated the micrococci in bottles of liquid culture medium, Ogston found that the micrococci grew feebly in the depths of the medium, but not at all at the surface. He concluded that micrococci must belong to the group of organisms that had been described by Louis Pasteur in an April 1878 lecture before the Paris Academy of Medicine as anaerobes. ${ }^{21}$ Pasteur suggested that the differences between aerobic and anaerobic organisms might be used to separate them in pure culture. ${ }^{22}$ Ogston then thought of growing the micrococci in the interior of fresh hens' eggs, which he thought would provide an anaerobic environment, and found they grew rapidly within an egg to give a pure culture. A drop of such a culture injected beneath the skin of a guinea pig produced an abscess; ordinary egg white did not.

By March 1881, when Ogston published a more complete report of his work in the British Medical Journal, he had examined eighty-two abscesses, of which thirteen were "cold" or chronic abscesses, and sixty-five were acute abscesses. In 1878, the Swiss surgeon Theodor Kocher had suggested that all acute inflammations were caused by micro-organisms, and, because Ogston consistently found micrococci in the pus of acute abscesses, he was inclined to hold the same opinion. ${ }^{23}$ Ogston thought that the micrococci were probably the cause of inflammation in acute abscesses because clearly they had been growing, their growth being indicated by their occurrence in chains or clusters. In abscesses in which the micrococci occurred in clusters, usually there were no chains, but some abscesses contained both chains and groups.

${ }^{20}$ In 1880, surgeons used the term cold abscess to mean simply an abscess without inflammation. Although they knew that many forms of such cold or chronic abscesses were connected with diseased bones and joints and might result from a tubercle, they did not consider cold abscesses, as a class, tuberculous, as is assumed today. Various observers noted that the pus of cold abscesses was free of micro-organisms. See Sir John Ericksen, The science and art of surgery, 8th ed., Philadelphia, 1884, pp. 250-251.

${ }^{21}$ Louis Pasteur, J. F. Joubert, and C. E. Chamberland, 'La théorie des germes et ses applications à la médecine et la chirurgie', Bull. Acad. Méd., 1878, ser. 2, 7: 432-453. In attempting to cultivate the organism that he had discovered in 1866 and named the vibrion septique, Pasteur and his colleagues found that it would not grow in the presence of air, but would grow either in a vacuum or in an atmosphere of carbon dioxide. It was, therefore, an obligate anaerobe capable of growing and multiplying only in the absence of oxygen. The vibrion septique thus was distinguished from the anthrax bacillus, which required oxygen for its growth and was, therefore, an aerobe.

22 Ibid.

${ }^{23}$ Theodor Kocher, 'Zur Aetiologie der acuten Entzundungen', Arch. klin. Chir., 1878, 23: 101-116; cf. Alexander Ogston, 'Report upon micro-organisms in surgical diseases', Br. med. J., 1881, i: 369-375, p. 370. 
Because the micrococci were associated so closely with the occurrence of acute abscesses, Ogston decided to determine whether injections of micrococci could produce abscesses in such experimental animals as guinea pigs, white mice, and wild mice. Injections of pus from cold abscesses (containing no micrococci) had no effect, but injections of pus from acute abscesses made the animals severely ill. Ogston wrote, "The animals refused food, sat cowering in a retired place in their case, were listless and apathetic, their coat [sic] was disordered and sometimes wet, their eyes were kept closed save when startled, and the mice showed the purulent conjunctivitis and glueing together of the eyelids described by Koch in his experiments on septicaemia."24 Micrococci were found in the heart blood. Around the injection site there formed an abscess in the pus of which multitudes of micrococci grew. A drop of the pus injected into a second animal produced the same results, as did a drop of pus from the second animal injected into a third, and so on. The kind of micrococci produced in the experimental animals was determined by the kind of micrococci injected, chainforming micrococci gave rise to chain-forming micrococci, and cluster forms to cluster forms. After five to seven days, the animals began to recover. The micrococci disappeared from the heart blood while the abscess at the injection site became swollen and more sharply separated from the surrounding tissues.

When Ogston mixed pus containing micrococci with equal parts of a five per cent solution of carbolic acid, the mixture produced no reaction when injected into a guinea pig. Similarly, the heating of pus to $130^{\circ} \mathrm{F}$ destroyed its ability to produce infection.

Ogston's demonstration that micrococci derived from the pus of acute abscesses were capable of producing inflammation and suppuration contradicted Watson Cheyne's conclusions of 1878 , although not his observations, as Ogston noted ${ }^{25} \mathrm{At}$ the International Medical Congress held in London in October 1881, Watson Cheyne's teacher, Joseph Lister, criticized Ogston's work. ${ }^{26}$ Lister pointed out that not all inflammations were caused by invasions of micro-organisms; some were caused by counter-irritants. Inflammation, Lister thought, might often be caused through the nervous system, as John Hunter had said. He cited several anecdotes to illustrate the sympathy of one part of the body with another, and ended by suggesting that inflammation might be caused by an abnormal action of the nerves on a part of the body inflamed.$^{27}$ Although Lister accepted Ogston's observations of the presence of micrococci in the pus of acute abscesses, he denied that they were really the cause of suppuration because, if they were, they would also have to be the cause of the inflammation that preceded the suppuration. But such inflammation might be induced, Lister asserted, "by some altogether accidental circumstance." 28 Lister suggested that micrococci gained entrance to the body as a secondary consequence of inflammation, rather than being the cause of the inflammation. He concluded, "whether as regards the etiology [sic] or the treatment of inflammation, it would be a

${ }^{24}$ Ibid., p. 371.

25 Ibid., p. 372.

${ }^{26}$ Joseph Lister, 'An address on the relation of micro-organisms to inflammation', Lancet, 1881, ii: 695-698.

${ }^{27}$ Ibid., p. 696.

${ }^{28}$ Ibid., p. 697. 


\section{Leonard G. Wilson}

giant mistake to disregard the influence of the nervous system."29

Lister's paper was an embarrassing lapse on the part of a great man. He cited no experiments and failed entirely to discuss Ogston's experiments and observations. Lister was clearly the prisoner of his earlier belief that the pus in an unopened abscess was, as a rule, free of micro-organisms. Pus, he thought, was sterile and was not subject to putrefaction until it came into contact with micro-organisms in the air after an abscess was opened. ${ }^{30}$ Pus was formed as a result of inflammation, or irritation of the tissues. In 1867, he said, "In an ordinary abscess, whether acute or chronic, the original cause that led to suppuration is no longer in operation, and the stimulus that determines the continued pus formation is derived from the presence of the pus pent up in the interior." ${ }^{31}$ Hence abscesses needed to be opened and drained, but they must be opened antiseptically, Lister believed, to prevent decomposition of the pus on its exposure to the air. In 1881, he still held to his opinion of 1867.

When, in 1882, Ogston answered Lister's paper, he pointed out that the various anecdotes related by Lister had nothing to do with inflammation. He denied that counter-irritation exerted any influence on inflammation. ${ }^{32}$ After thoroughly criticizing Lister's reasoning, Ogston cited various reports of the presence of micrococci in the blood or tissues of patients dead from septicaemia or pyaemia. ${ }^{33} \mathrm{He}$ then proceeded to his real subject, namely, the true nature of septicaemia and pyaemia. Ogston emphasized that micrococci could be seen clearly under the microscope only if one used an oil immersion objective lens, an Abbe condenser, proper illumination, and aniline stains. Observations made without adequate microscopic technique were worthless, and if observers failed to describe the methods they had used, their observations could not be accepted until they did. With proper technique, "the clear round body of the micrococcus, even when isolated from any of its neighbours, as sharp-cut and clear-edged as the moon in the sky, is always to be discriminated from the organic granules that have been said in such liquids to resemble them." ${ }^{34}$ Because micrococci, when present, could be seen clearly, Ogston was certain both from his own observations and those of others that they were not present in the blood and tissues of healthy persons. ${ }^{35}$. Lister had long argued that the tissues were normally sterile, and had made this premise the basis for antiseptic surgery. By contrast, micrococci grew abundantly on the surface of the skin, especially in protected areas as between the toes or beneath the fingernails.

Ogston argued that investigators had been misled by the term septicaemia or blood poisoning to look for the seat of disease in the blood, whereas septicaemia was actually a disease existing in the solid tissues, from which the blood might be affected

${ }^{29}$ Ibid., p. 698.

30 "In an unopened abscess . . ., as a general rule, no septic organisms are present, so that it is not necessary to introduce the carbolic acid into the interior." Joseph Lister, 'On a new method of treating compound fracture, abscess, etc. with observations on the conditions of suppuration' [1867] in Lister, The collected papers, 2 vols., Oxford University Press, 1909, vol. 2, pp. 1-36, p. 32.

31 Ibid., p. 34.

32 Alexander Ogston, 'Micrococcus poisoning', J. Anat. Physiol., Lond., 1882, 16: 526-567, p. 533-534.

${ }^{33}$ Ibid., pp. 545-546.

34 Ibid., pp. 550-551.

${ }^{35}$ Ibid., p. 556. 
secondarily by the secretion into it of poisons that Ogston referred to as ptomaines. Only a few micrococci might find their way into the blood, but the number that did so was roughly in proportion to the severity of the disease. By 1882, Ogston had become confident that micrococci existed in two distinct forms that did not pass into each other: those in chains, the Streptococcus of Billroth; and those in clusters, which Ogston now named Staphylococcus. ${ }^{36}$ Ogston described what he called "sloughing inflammation or inflammatory mortification" as a result of invasion of the tissues by staphylococcus through an infected wound. ${ }^{37}$ By contrast, wound infections accompanied by erysipelas, or an erysipelatoid reddening, were all due to streptococcus infection. ${ }^{38}$ Ogston noted that the hectic fever associated with the later stages of phthisis occurred as a result of the suppurative breakdown of lung tissue. Because micrococci were always present in the expectorations of patients with hectic fever, it must be considered a septicaemia associated with ulceration of the lungs in the final stages of phthisis.

Ogston acknowledged that a principal objection to the idea that micrococci could be the cause of septicaemia, pyaemia, and erysipelas in all their variant forms was that it was difficult to understand how any organism could produce such a great variety of disease. Yet he had shown that micrococci existed in two forms, the Streptococcus and the Staphylococcus, each of which produced a different group of diseases. The disease might vary also according to the organ or structure invaded, the virulence of the micro-organism, and the susceptibility of the infected individual. ${ }^{39}$

Alexander Ogston's observations of streptococcus and staphylococcus in the pus of acute abscesses and his experimental demonstrations that the micro-organisms were the cause of abscesses came at a time when investigators were finding the streptococcus in a variety of diseases. In 1879, Louis Pasteur's interest was aroused in puerperal fever when he heard a lecture on 12 March by a Dr Hervieux, who argued against the application of the germ theory to the aetiology of puerperal theory. Hervieux concluded his talk by saying derisively that he feared he would die before the vibrio that caused puerperal fever would be discovered. ${ }^{40}$ Pasteur, who was present in the audience, rose immediately to the challenge and drew, apparently on a blackboard, the micro-organism "to which I am brought at this moment to attribute the existence of this fever."41 What he drew was a short chain of spherical granules, that is, a streptococcus. When he spoke, Pasteur had made no study of puerperal fever, but he had seen such organisms in some fermentations and in the intestine of the silkworm, in his study of silkworm disease. He was aware, too, that various German authors had described such organisms in many pathological conditions, including puerperal fever, and referred to them as microsporon or micrococcus. ${ }^{42}$ Pasteur added that, in 1875 , he had visited the Paris hospitals to study abscesses and that in various abscesses he had

${ }^{36}$ Alexander Ogston, 'Micrococcus poisoning', J. Anat. Physiol., London, 1883, 17: 24-58, p. 27.

37 Ibid., pp. 37-40.

38 Ibid., pp. $42-44$.

39 Ibid., p. 54.

40 “J'ai un peur terrible ... c'est celle de mourir avant qu'on n'ait découvert ce vibrion-là." Hervieux,

'Septicémie puerpérale', Bull. Acad. Méd., 1879, ser. 2, 8: 238-256.

4 Louis Pasteur, 'Septicémie puerpérale', ibid., pp. 256-260, p. 259, translation mine.

42 Ibid., pp. 259-260. 
found multitudes of such small round organisms in pairs or in chains, like strings of beads. ${ }^{43}$

The day after their confrontation at the Academy of Medicine, Hervieux invited Pasteur to come to his service at La Maternité hospital to see a woman gravely ill with puerperal fever. From samples of blood taken from the patient's finger Pasteur was able to cultivate a micrococcus that grew in long chains, similar to those that he had found in the pus of abscesses in $1875 .{ }^{44}$ The patient died on 16 March, and Pasteur attended the autopsy on the 17th. From the pus in the abdominal cavity, from the blood, and from the lining of the uterus he was able to cultivate the same chain-forming micrococcus. ${ }^{45}$ Pasteur distinguished the chain-forming micrococcus from a micrococcus in pairs (a diplococcus) that he found commonly in pus. In one patient from whom he could cultivate no organisms, Pasteur ventured to predict that she would recover, and his prediction proved accurate. Pasteur attributed puerperal fever to the invasion of micro-organisms through the wounded surface of the uterus following childbirth. To prevent puerperal fever, he recommended the use of antiseptic method with such antiseptics as carbolic acid and boric acid.

In 1882, the German surgeon Friedrich Fehleisen, an assistant in the surgical clinic at Würzburg, described streptococci growing in the lymph vessels and subcutaneous fatty tissue of the reddened area of the skin in patients suffering from erysipelas. In the skin along the margin of the reddened area, Fehleisen found the streptococci multiplying in the lymph vessels and fatty tissue. The reddened area itself was marked by a striking infiltration of nucleated host cells that engulfed the streptococci and ultimately consumed them entirely. Fehleisen identified the spreading red blush of erysipelas as an inflammatory reaction of the host tissues, a reaction that was part of the system of body defences against the invading streptococci. ${ }^{46}$ He thought that erysipelas was caused by a specific streptococcus.

The following year, 1883, Fehleisen published a small monograph on the aetiology of erysipelas in which he described additional experiments that he had performed to provide conclusive proof that the streptococcus occurring in the lymph vessels and subcutaneous connective tissue of the reddened patches of skin was the cause of erysipelas. Using techniques developed by Robert Koch, Fehleisen cut out with scissors heat-sterilized small pieces of reddened erysipelatous skin that had been thoroughly washed and disinfected, and placed the snips of skin in a nutrient gelatine, first liquified, then incubated at $20^{\circ} \mathrm{C}$. After two days, there grew out from the pieces of skin pure cultures of streptococcus that Fehleisen transferred to fresh nutrient gelatine or to coagulated blood serum on which he found the cultures flourished with a characteristic mode of growth.

When Fehleisen inoculated pure cultures of the streptococcus into the ears of rabbits, he was able to produce a typical erysipelas. Fehleisen also inoculated the

\footnotetext{
${ }^{43}$ Louis Pasteur, 'De l'extension de la théorie des germes à l'étiologie de quelques maladies communes', C.r. hebd. Séanc. Acad. Sci., Paris, 1880, 90: 1033-1044; reprinted in Louis Pasteur, Oeuvres, ed. Pasteur Vallery-Radot, 7 vols., Paris, Masson, 1922-39, vol. 6, pp. 147-158.

44 Ibid., vol. 6, p. 152.

45 Pasteur, op. cit., note 41 above, pp. 259-260.

${ }^{46}$ [Friedrich] Fehleisen, 'Mittelheilungen aus der Würzburger chirurgischen Klinik. 5. Ueber Erysipel', Dt . Z. Chir., 1882, 16: 391-397.
} 
erysipelas streptococcus into human patients. He thought himself justified in inoculating a patient with an admittedly dangerous infectious disease because physicians were then using erysipelas to combat various forms of cancer and claiming some measure of success. On 21 August 1882, Fehleisen inoculated the streptococcus into the tumours of a fifty-eight-year-old woman suffering from multiple fibrosarcoma of the skin. After three days, the patient developed fever, and erysipelas spread over extensive areas of skin. During the erysipelas, the main mass of the tumour swelled considerably, but after recovery the tumour partially degenerated. The therapeutic benefit was not sufficient to justify a second inoculation with erysipelas, because the infection had itself proved dangerous to the patient.

On 15 September 1882, Fehleisen inoculated a second patient, a woman forty-nine years of age who had been operated on three times during the previous two years for carcinoma of the breast. She now had a new tumour, five to six centimetres in diameter in the old scar. The second day after inoculation, the woman developed a fever and showed erysipelas spreading from the inoculation site. Eight days after inoculation, she was free from fever and felt well, but still showed a spreading erysipelas. Her tumours had disappeared completely.

Fehleisen inoculated five other patients suffering from such conditions as sarcoma, mammary carcinoma, and lupus, with variable results. He considered that his observations were too few to establish the therapeutic value of erysipelas, but they did demonstrate clearly that erysipelas could be produced by inoculation of the skin with a pure culture of streptococcus. Fehleisen thus completed the proof that the erysipelas was caused by a streptococcus. ${ }^{47}$

In 1884, another German surgeon, Friedrich Julius Rosenbach, working at Göttingen, found streptococci in the pus of wound infections. ${ }^{48} \mathrm{He}$ observed that it was difficult to complete the proof that the streptococci were the actual cause of wound disease because experimental animals such as mice and rabbits were frequently not susceptible to human infections. Rosenbach was certain that streptococcus was not a single species, but a genus. He distinguished the streptococcus of erysipelas described by Fehleisen from the streptococcus that he had isolated from the pus of wound infections, which he named Streptococcus pyogenes. Under the microscope Streptococcus erysipelatosus and Streptococcus pyogenes looked exactly alike, but when grown in pure culture on plates of agar, gelatine, or coagulated blood serum the cultures possessed different characteristics. The colonies of the streptococcus of erysipelas were whiter and more opaque than those of Streptococcus pyogenes and they had dendritic projections that made older cultures resemble a fern leaf. Older cultures of Streptococcus pyogenes looked more like the leaf of an acacia. Under the microscope, both the chains and individual cocci of the erysipelas streptococcus seemed somewhat larger than those of Streptococcus pyogenes.

\footnotetext{
${ }^{47}$ [Friedrich] Fehleisen, 'On erysipelas', trans. Leslie Ogilvie, in W. Watson Cheyne (editor), Bacteria in relation to disease, London, 1886, pp. 261-286.

${ }^{48}$ A. J. F. Rosenbach, Microorganismen bei den Wundinfektionskrankheiten des Menschen, Wiesbaden, 1884; translated in abridged form as Friedrich Julius Rosenbach, 'Recent researches on micro-organisms in relation to suppuration and septic diseases', trans. W. Watson Cheyne, in Cheyne (editor), op. cit., note 47 above, pp. $397-438$.
} 


\section{Leonard G. Wilson}

A striking feature of the streptococcus and especially of the streptococcus of erysipelas, Rosenbach noted, was its ability to spread through extensive tracts of the host tissues, and live in them, without destroying the tissues or causing suppuration. Although Rosenbach thought that the erysipelas streptococcus could not cause suppuration, he had made observations that suggested that the pus-forming streptococcus could associate itself very easily with the erysipelas streptococcus. When suppuration occurred in connexion with erysipelas, he thought that two distinct streptococci were involved.

Rosenbach also confirmed Ogston's finding that septicaemia was caused by a micrococcus infection, specifically by a streptococcus that he identified as Streptococcus pyogenes. He wrote, "Where one finds, scattered in the tissue attacked but still alive, coccus lying beside coccus, and chain beside chain ...., while no other microbe, as far at any rate as the microscope shows, can be detected, one must lay the blame on the streptococcus." 49 Rosenbach concluded as a general result of his investigations that the cause of metastatic pyaemia was identical with that of local acute abscesses, namely, the Streptococcus pyogenes. Staphylococcus aureus might likewise cause a metastatic pyaemia, but much more frequently the malignant forms of pyaemia were the result of streptococcus infections.

Although Rosenbach thought the streptococcus found in the pus of acute abscesses, Streptococcus pyogenes, was distinct from the streptococcus shown by Fehleisen to be the cause of erysipelas, Streptococcus erysipelatosus, in 1889 Ferdinand Widal, working at the Pasteur Institute at Paris, argued that they were one and the same organism, which was identical also with the streptococcus that Pasteur had demonstrated to be the cause of puerperal fever. Streptococci were at first thought to belong to a number of different species because they were found in such a great variety of lesions. When investigators such as Widal decided that they were working with a single species, they had to postulate that the one species, Streptococcus pyogenes, could vary enormously in virulence. Streptococci might be found living harmlessly in the mouth, or they might cause a septic sore throat. In the skin, they might cause erysipelas; in wounds, they might cause septicaemia. In women, following childbirth, they might cause puerperal fever. In lobular pneumonia following measles, typhoid fever, scarlet fever, or diphtheria, streptococci were found abundantly in the lungs. Streptococci also occurred in the lungs in victims of tuberculosis who had experienced a hectic fever in the later stages of their illness.

Many investigators refused to believe that one species of Streptococcus could be the cause of so many different pathological conditions. Instead, following Theodor Billroth, they argued that the streptococcus merely accompanied the disease as a secondary invader; it could not be the cause of the disease. In the presence of such doubts, additional confusion was caused by the theory that streptococci could readily change from one species to another, or undergo marked changes in virulence in passage through a series of animals. Nevertheless, by 1890 , the role of streptococci in surgical infections and in erysipelas was clear, but in scarlet fever and puerperal fever it remained in question.

49 Ibid., p. 429. 